\title{
Steroid hormones in uterine washings and in plasma of gilts between Days 9 and 15 after oestrus and between Days 9 and 15 after coitus
}

\author{
B. A. Stone and R. F. Seamark \\ Department of Obstetrics and Gynaecology, University of Adelaide, The Queen Elizabeth Hospital, \\ Woodville, South Australia 5011, Australia
}

\begin{abstract}
Summary. Between Days 9 and 15 after oestrus, concentrations of pregnenolone, pregnenolone sulphate, dehydroepiandrosterone (DHEA), DHEA sulphate, androstenedione, oestrone and oestrone sulphate in free uterine fluid collected from non-pregnant gilts were greater than respective values in plasma $(P<0.05)$. The total contents of pregnenolone, progesterone, DHEA, testosterone, oestrone and oestradiol in washings from pregnant uteri exceeded $(P<0.05)$ respective non-pregnancy levels during this same period.

Concentrations of pregnenolone, pregnenolone sulphate, DHEA, DHEA sulphate, androstenedione, oestrone, oestrone sulphate and oestradiol in free uterine fluid recovered from gravid uteri were also higher $(P<0.05)$ than respective plasma values. By contrast, the progesterone concentration in uterine fluid from pregnant animals was lower $(P<0.001)$ than the plasma value.

Concentrations of DHEA, DHEA sulphate, androstenedione and oestrone sulphate in plasma of pregnant gilts between Days 9 and 15 after mating exceeded $(P<0.05)$ the respective concentrations in unmated gilts between Days 9 and 15 after oestrus. Plasma levels of pregnenolone sulphate were lower $(P<0.05)$ in the pregnant animals.

We therefore suggest that the endometrium of the pig can concentrate steroid hormones in uterine fluid and that increases in steroid levels in this milieu between Days 9 and 15 after coitus reflect steroidogenesis by embryonic tissues and modification of enzyme activities within uterine tissues under the influence of progestagens. The pool of steroid sulphoconjugates present in uterine fluid between Days 9 and 15 post coitum could serve as an important precursor source for progestagen, androgen and oestrogen synthesis by tissues of pig embryos before implantation.
\end{abstract}

\section{Introduction}

Between Days 9 and 15 after fertilization, viable pig blastocysts change from spheres to filaments (Anderson, 1978); this change is associated with cellular remodelling in the endoderm and trophectoderm and an exponential increase in protein content (Geisert, Thatcher, Roberts \& Bazer, 1982a; Wright, Grammer, Bondioli, Kuzan \& Menino, 1983) and results in a higher ratio of trophoblast area/blastocyst volume. Trophoblast expansion increases the area of apposition of trophectoderm and endometrium at implantation (between Days 14 and 18 post coitum; Perry, 1981). Blastocysts that fail to elongate are then at a competitive disadvantage before and at implantation and it is proposed that this failure accounts for some of the embryonic loss that occurs between Days 9 and 15 of gestation in the pig (about 25\%; Scofield, Clegg \& Lamming, 1974). If determinants of blastocyst growth can be identified and corrected, this high level of early embryonic wastage in sows may be reduced. 
Because growth factors for protein anabolism in preimplantation blastocysts in vivo are provided from endometrial secretions via the uterine 'milk', we have attempted to identify steroidal determinants of preimplantation blastocyst growth by analysing uterine flushings collected from gilts between Days 9 and 15 after coitus. In this regard, steroids of particular interest include those that are known to stimulate release of proteins by the pig endometrium (predominantly progesterone and oestrogens; Schlosnagle, Bazer, Tsibris \& Roberts, 1974; Basha, Bazer \& Roberts, 1979; Aitken, 1979; Adams, Bazer \& Roberts, 1981; Fazleabas, Bazer \& Roberts, 1982; Geisert et al., 1982a). Furthermore, because endometrial secretion is stimulated during pregnancy in the pig (Knight, Bazer \& Wallace, 1973; Basha et al., 1980; Geisert, Renegar, Thatcher, Roberts \& Bazer, $1982 \mathrm{~b}$ ) and pig conceptuses have the ability to synthesize steroids de novo (Flint, Burton, Gadsby, Saunders \& Heap, 1979; Heap, Flint, Gadsby \& Rice, 1979), levels of steroids in washings of gravid uteri are compared with the values in uterine fluids collected from unmated gilts between Days 9 and 15 after oestrus, before the normal onset of luteolysis (Henricks, Guthrie \& Handlin, 1972). Further comparison is made to the steroid content of plasma.

\section{Materials and Methods}

\section{Animals}

Large White sows (16 unmated and 16 mated) were slaughtered 9-15 days after the day of onset of the previous oestrus. Immediately after recovery of uteri, each uterine horn was cannulated above the bifurcation and flushed from the utero-tubal junction, towards the cannula (Stone, Whyte, Pointon, Quinn \& Heap, 1984), with $10 \mathrm{ml} 0.9 \%(\mathrm{w} / \mathrm{v}) \mathrm{NaCl}$ at $4^{\circ} \mathrm{C}$. Flushings were transported in ice to the laboratory and there centrifuged at low speed $\left(56 \mathrm{~g}, 20 \mathrm{~min}, 4^{\circ} \mathrm{C}\right)$ to precipitate conceptus tissue and/or other particulate matter. Supernatants were portioned and stored at $-15^{\circ} \mathrm{C}$. Precipitates from flushings of tracts of mated gilts were examined microscopically to confirm the presence of conceptus tissues consistent with stage of pregnancy (Anderson, 1978). Numbers of corpora lutea (CL) associated with individual uterine horns were recorded.

Blood samples (mixed arterial and venous) collected from all animals at exsanguination were centrifuged $\left(2011 \mathrm{~g}, 20 \mathrm{~min}, 4^{\circ} \mathrm{C}\right)$ and plasma samples were stored at $-15^{\circ} \mathrm{C}$.

Concentrations of steroid hormones in samples of plasma and in flushings from each uterine horn were determined by radioimmunoassay.

Days of slaughter were organized to provide post-mortem samples from a minimum of 2 gilts on each of Days 9 through 15 after oestrus/coitus.

\section{General assay methods}

Solvents for extraction were of analytical reagent grade and were redistilled before use. The solvent:sample ratio $(\mathrm{v} / \mathrm{v})$ exceeded 10:1 in all assays. Solvent was removed from sample extracts at $37^{\circ} \mathrm{C}$ under air.

Unconjugated steroid standards were purchased from Steraloids (Wilton, NH, U.S.A.) and pregnenolone sulphate (sodium salt) and oestrone-3-sulphate (potassium salt) from Sigma Chemical Company (St Louis, MO, U.S.A.). Standard steroids were not recrystallized further.

In the assays of pregnenolone sulphate, dehydroepiandrosterone (DHEA), DHEA sulphate and oestrone sulphate in plasma and in uterine washings, evaporated standards were equilibrated with steroid-free plasma or saline respectively (volumes equivalent to sample volume), then extracted and assayed with the uterine washing/plasma samples.

Before assay of pregnenolone, progesterone, androstenedione, oestrone, testosterone and oestradiol, solvent extracts of plasma and uterine flushings were fractionated by column chromatography (hydroxyalkoxypropyl Sephadex; Lipidex, Packard Instrument Company, IL, U.S.A.; column bed dimensions $80 \mathrm{~mm} \times 3 \mathrm{~mm}$ ), as detailed below. 
For pregnenolone and progesterone, samples $(250 \mu \mathrm{l})$ were extracted with $2.5 \mathrm{ml}$ hexane:ethyl acetate $(9: 1 \mathrm{v} / \mathrm{v})$. The solvent was removed and residues redissolved in $200 \mu \mathrm{l}$ hexane:ethyl acetate $(9: 1 \mathrm{v} / \mathrm{v})$ and carefully loaded on to the column bed. Elution was made with $1.0 \mathrm{ml}$ hexane (discard), $2.5 \mathrm{ml}$ hexane (progesterone fraction, $77 \%$ recovery), a further $1.0 \mathrm{ml}$ hexane (discard) and $2.5 \mathrm{ml}$ hexane:ethyl acetate $(9: 1 \mathrm{v} / \mathrm{v}$; pregnenolone fraction, $93 \%$ recovery).

For androstenedione, testosterone, oestrone and oestradiol, samples $(400 \mu \mathrm{l})$ were extracted with $2.5 \mathrm{ml}$ heptane:ethyl acetate $(2: 3 \mathrm{v} / \mathrm{v})$, the solvent removed and residues redissolved in $200 \mu \mathrm{l}$ hexane:ethyl acetate $(9: 1 \mathrm{v} / \mathrm{v})$ and loaded. Elution was made with $0.5 \mathrm{ml}$ hexane:ethyl acetate $(9: 1 \mathrm{v} / \mathrm{v}$; discard $), 2.0 \mathrm{ml}$ hexane:ethyl acetate $(9: 1 \mathrm{v} / \mathrm{v}$; androstenedione fraction, $71 \%$ recovery), $2.0 \mathrm{ml}$ hexane:ethyl acetate $(9: 1 \mathrm{v} / \mathrm{v}$; testosterone fraction, $93 \%$ recovery), $2.5 \mathrm{ml}$ hexane:ethyl acetate (4:1 v/v; oestrone fraction, $84 \%$ recovery) and $2.0 \mathrm{ml}$ ethyl acetate (oestradiol fraction, $96 \%$ recovery). Tritiated tracers were purchased from New England Nuclear (Boston, MA, U.S.A.). The assay buffer contained $6.1 \mathrm{~g} \mathrm{NaH}_{2} \mathrm{PO}_{4} .2 \mathrm{H}_{2} \mathrm{O}, 10.9 \mathrm{~g} \mathrm{Na}_{2} \mathrm{HPO}_{4} .2 \mathrm{H}_{2} \mathrm{O}, 9.0 \mathrm{~g} \mathrm{NaCl}, 1.0 \mathrm{~g} \mathrm{NaN}_{3}$ and $1.0 \mathrm{~g}$ bovine serum albumin (BSA; Sigma) per litre, and was $\mathrm{pH}$ adjusted to 7.0. After incubation of sample/standard extracts with tracer and antiserum, antibody-bound steroid was precipitated by the addition of $1 \mathrm{mg}$ gamma-globulin and polyethylene glycol 6000 (to provide a final concentration of $20.6 \%$ ). After vortexing, tubes were centrifuged $\left(4^{\circ} \mathrm{C}, 3574 \mathrm{~g}, 20 \mathrm{~min}\right)$ and the supernatant, containing free steroid, was aspirated and discarded. Precipitated pellets, containing protein-bound steroid, were resuspended in $1.8 \mathrm{ml}$ Scintisol (Isolab Incorporated, Akran, OH, U.S.A.), and radioactivity was measured in a Tracor Analytic 6891 liquid scintillation spectrometer.

Intra-assay coefficients of variation were $<10 \%$ in all assays. All uterine washing and plasma samples were assayed in single assays with blanks derived from saline or steroid-free pig plasma respectively.

\section{Specific assays}

Pregnenolone. After chromatography, solvent was removed from the pregnenolone fraction and pregnenolone was determined using an antiserum raised in goats against pregnenolone-3carboxymethyloxime (CMO)-gamma globulin. The cross-reactivity of the antiserum, used at a final dilution of $1: 16000$, was $37.5 \%$ with progesterone, $9.95 \%$ with $5 \alpha$-pregnan-3-ol-20-one, $4.44 \%$ with $5 \alpha$-pregnan-3,20-dione, $0 \cdot 21 \%$ with $17 \alpha$-hydroxyprogesterone, $0 \cdot 18 \%$ with DHEA, $0 \cdot 15 \%$ with DHEA sulphate, and $<0 \cdot 10 \%$ with $17 \alpha$-hydroxypregnenolone, $20 \alpha$-hydroxypreg-4ene-3-one, androstenedione, oestradiol, oestrone, oestrone sulphate and testosterone. The limit of sensitivity of the assay was $0 \cdot 1 \mathrm{pmol}$ per tube.

Pregnenolone sulphate. Unconjugated steroids were extracted from uterine washing plasma samples with $2.0 \mathrm{ml}$ hexane:ethyl acetate $(9: 1 \mathrm{v} / \mathrm{v})$ and discarded. The remaining pellet was saturated with $\mathrm{NaCl}$ and extracted with $2.5 \mathrm{ml}$ ethyl acetate saturated with distilled water, the solvent was removed and the residue assayed using the same antiserum as employed in pregnenolone immunoassay. Levels of unconjugated steroids present in the pregnenolone sulphatecontaining extracts were $<5 \%$ of levels in the original media. For assay, extracts were dispensed into polypropylene tubes, into which any unconjugated steroid would be adsorbed (Bruning, Jonker \& Boerema-Baan, 1981), further diminishing any contribution of these compounds to levels of pregnenolone sulphate determined by this radioimmunoassay technique. The limit of sensitivity of the assay was $0.2 \mathrm{pmol}$ pregnenolone sulphate per tube.

$D H E A$. Samples were extracted with $2.5 \mathrm{ml}$ heptane:ethyl acetate $(2: 3 \mathrm{v} / \mathrm{v})$, the solvent was removed and DHEA determined using an antiserum raised in goats against DHEA-15 $\beta$-(3thiopropionic acid)-BSA. The cross-reactivity of the antiserum, used at a final dilution of 1:5000, was $0.20 \%$ with androstenedione, $0.09 \%$ with DHEA sulphate, $0.06 \%$ with testosterone and $<0.04 \%$ with $5 \alpha$-dihydrotestosterone, progesterone, oestradiol and pregnenolone. The limit of sensitivity of the assay was $0 \cdot 1 \mathrm{pmol}$ per tube. 
DHEA sulphate. Unconjugated steroids were extracted from samples with heptane:ethyl acetate $(2: 3 \mathrm{v} / \mathrm{v})$ and discarded. The remaining pellet was saturated with $\mathrm{NaCl}$ and extracted with $2.5 \mathrm{ml}$ ethyl acetate saturated with water. Dried extracts were assayed for DHEA sulphate using an antiserum raised in goats against DHEA-hemisuccinate-BSA. The cross-reactivity of the antiserum, used at a final dilution of $1: 1000$, was $67.3 \%$ with DHEA, $10 \%$ with androstenedione, $0.08 \%$ with testosterone, $0.07 \%$ with dihydrotestosterone and $<0.02 \%$ with progesterone and oestradiol. Levels of these unconjugated steroids in the DHEA sulphate-containing extracts were $<2 \%$ of levels in the original media. The limit of sensitivity of the assay was $0 \cdot 1 \mathrm{pmol}$ per tube.

Progesterone. After removal of solvent from the chromatography fractions, residues were assayed for progesterone using an antiserum raised in goats against progesterone-11 $\alpha$ hemisuccinate-gamma globulin. Used at a final dilution of 1:7000, the cross-reactivity of the antiserum was $1.2 \%$ with $17 \alpha$-hydroxyprogesterone, $0.44 \%$ with pregnenolone, $0.17 \%$ with $20 \alpha$-hydroxypreg-4-ene-3-one and $<0.07 \%$ with androstenedione, cortisol, testosterone and oestradiol. The limit of sensitivity of the assay was $0 \cdot 1$ pmol per tube.

Androstenedione. Solvent was removed from the chromatography fractions and residues were assayed for androstenedione using an antiserum raised in sheep against androstenedione-3CMO-BSA. Used at a final dilution of $1: 75000$, the cross-reactivity of the antiserum was $2 \cdot 6 \%$ with DHEA, $1.18 \%$ with testosterone, $0.33 \%$ with $5 \alpha$-dihydrotestosterone, $0.27 \%$ with progesterone and $17 \alpha$-hydroxyprogesterone and $<0.03 \%$ with oestradiol and cortisol. The limit of sensitivity of the assay was $0.1 \mathrm{pmol}$ androstenedione per tube.

Oestrone. Dried chromatography fractions containing oestrone were assayed for oestrone using an antiserum raised in sheep against oestrone-3-CMO-gelatin. Used at a final dilution of 1:30 000, the cross-reactivity of the antiserum was $83 \%$ with oestrone sulphate (not extracted into the organic phase), $4.2 \%$ with oestrone-3-glucosiduronate and $<0.01 \%$ with 21 other $\mathrm{C}_{19}$ and $\mathrm{C}_{21}$ steroids/conjugates tested. The limit of sensitivity of the assay was $0.05 \mathrm{pmol}$ oestrone per tube.

Oestrone sulphate. After extraction of unconjugated steroids with ether, samples were saturated with $\mathrm{NaCl}$, oestrone sulphate was extracted with $2.0 \mathrm{ml}$ tetrahydrofuran and the solvent was removed. Residues were assayed for oestrone sulphate using the same antiserum as was used for oestrone, but at a final dilution of 1:33000. The limit of sensitivity of the assay was $0.01 \mathrm{pmol}$ oestrone sulphate per tube.

Oestradiol. After chromatography, solvent was removed from oestradiol fractions and residues were assayed for oestradiol using an antiserum raised in goats against oestradiol-6-CMO-gamma globulin. Used at a final dilution of 1:30 000, the cross-reactivity of this antiserum was $16.9 \%$ with oestrone, $1.1 \%$ with oestriol and $<0.02 \%$ with testosterone, androstenedione and progesterone. The limit of sensitivity of the assay was $0.04 \mathrm{pmol}$ oestradiol per tube.

Testosterone. Dried chromatography fractions containing testosterone were assayed for testosterone using an antiserum raised in goats against testosterone-15 $\beta$-(3-thiopropionic acid)BSA. Used at a final dilution of $1: 10000$, this antiserum cross-reacted $11.9 \%$ with $5 \alpha$-dihydrotestosterone, $0.3 \%$ with androstenedione, $0.24 \%$ with progesterone, $0.05 \%$ with pregnenolone and $<0.02 \%$ with DHEA and oestradiol. The limit of sensitivity of the assay was $0 \cdot 1$ pmol testosterone per tube.

\section{Statistics}

For each steroid measured, statistical differences between the values for pregnant and nonpregnant animals, and between plasma and uterine fluid, were analysed by Student's $t$ test (Clarke, 1969). For individual animals, relationships between numbers of CL and steroid properties of uterine washings (total steroid content and steroid concentration in free uterine fluid) and of 
plasma were examined by least squares linear regression analysis ( $\mathrm{Li}, 1969)$. Relationships between these same steroid values and days post coitum and days after oestrus were analysed similarly.

\section{Results}

Despite efforts to avoid rupture of the fragile trophectoderm tissues during collection of uterine flushings, disrupted membranes were seen when precipitated conceptus tissues were examined microscopically. Uterine washings collected from pregnant gilts in this study therefore include blastocoele fluids and, while the volume of fluid contributed from this source would be low, concentrations of steroids in blastocoele fluid may be high (Seamark \& Lutwak-Mann, 1972; Borland, Erickson \& Ducibella, 1977; Gadsby \& Heap, 1978) and at variance to concentrations in the uterine fluid which bathes blastocysts in vivo. Regardless, all steroidal components of the fluid intrauterine milieu (or precursors to these steroids) will have originated from maternal pools and differences between steroidal properties of uterine fluids collected from pregnant and from unmated gilts can be attributed to the presence of conceptus tissues. Analysis of these differences is the primary objective of this study. The admixture of histotroph with blastocoele fluid is hereafter referred to as free uterine fluid.

The total recovered flush volume exceeded $10 \mathrm{ml}$ in 24/32 non-pregnant and in 20/32 pregnant uterine horns. Despite earlier evidence that endometrial secretion is enhanced during early pregnancy in sows (Murray, Bazer, Wallace \& Warnick, 1972; Knight et al., 1973; Bazer, 1975; Zavy, Bazer, Thatcher \& Wilcox, 1980; Basha et al., 1980; Geisert et al., 1982b), the overall average volume of free uterine fluid ( \pm s.e.m.) recovered from the gravid uterine horns $(11.7 \pm 4.3 \mathrm{ml})$ was not significantly higher than the respective non-pregnant value $(10 \cdot 1 \pm 3.6 \mathrm{ml} ; t$ test $)$.

Total levels of pregnenolone, progesterone, DHEA, testosterone, oestrone and oestradiol were higher $(P<0.05)$ in washings of pregnant uteri than of non-pregnant uteri between Days 9 and 15 after oestrus (Table 1), reflecting rising values for pregnant gilts after Day 10 post coitum (Text-fig. 1). Similarly, significant $(P<0.05)$ differences between pregnant and non-pregnant animals in regard to concentrations of pregnenolone, DHEA, DHEA sulphate, androstenedione, oestrone, oestrone sulphate and oestradiol in free uterine fluids (total volume of intrauterine fluid recovered, minus the volume of saline flush; Tables $2 \& 3$ ) can be attributed to divergence of pregnant and non-pregnant values after Day 9 post oestrus (Text-fig. 2).

Table 1. Total content of steroids in washes of single uterine horns of mated (pregnant, $n=32$ ) and of unmated (non-pregnant, $n=32$ ) gilts between Days 9 and 15 after oestrus

\begin{tabular}{llccl}
\hline & & \multicolumn{2}{c}{ Mean \pm s.e.m. steroid content (pmol/horn) } \\
\cline { 3 - 5 } & \multicolumn{1}{c}{ Steroid } & Non-pregnant & Pregnant & \\
\hline $\mathrm{C}_{21}$ & Pregnenolone & $26 \cdot 9 \pm 6 \cdot 5$ & $202 \cdot 1 \pm 46 \cdot 6$ & $* * *$ \\
& Pregnenolone sulphate & $65017 \pm 25583$ & $106865 \pm 41874$ & \\
& Progesterone & $86 \cdot 8 \pm 27 \cdot 6$ & $337 \cdot 0 \pm 108 \cdot 6$ & $*$ \\
$\mathrm{C}_{19}$ & DHEA & $3 \cdot 70 \pm 1 \cdot 44$ & $18 \cdot 7 \pm 2 \cdot 1$ & $* * *$ \\
& DHEA sulphate & $2959 \pm 1290$ & $937 \pm 469$ & \\
& Androstenedione & $14 \cdot 1 \pm 5 \cdot 1$ & $20 \cdot 4 \pm 6 \cdot 6$ & $*$ \\
& Testosterone & $2 \cdot 10 \pm 1 \cdot 08$ & $9 \cdot 40 \pm 3 \cdot 34$ & $*$ \\
$\mathrm{C}_{18}$ & Oestrone & $2 \cdot 92 \pm 0.72$ & $13 \cdot 92 \pm 4.05$ & $* *$ \\
& Oestrone sulphate & $1234 \pm 453$ & $404 \pm 199$ & \\
& Oestradiol & $0 \cdot 69 \pm 0 \cdot 21$ & $62 \cdot 96 \pm 32 \cdot 44$ & $*$ \\
\hline
\end{tabular}

Significantly different from value for non-pregnant sows: ${ }^{*} P<0.05 ;{ }^{* *} P<0.01 ;{ }^{* * *} P<0.001$ (Student's $t$ test). 

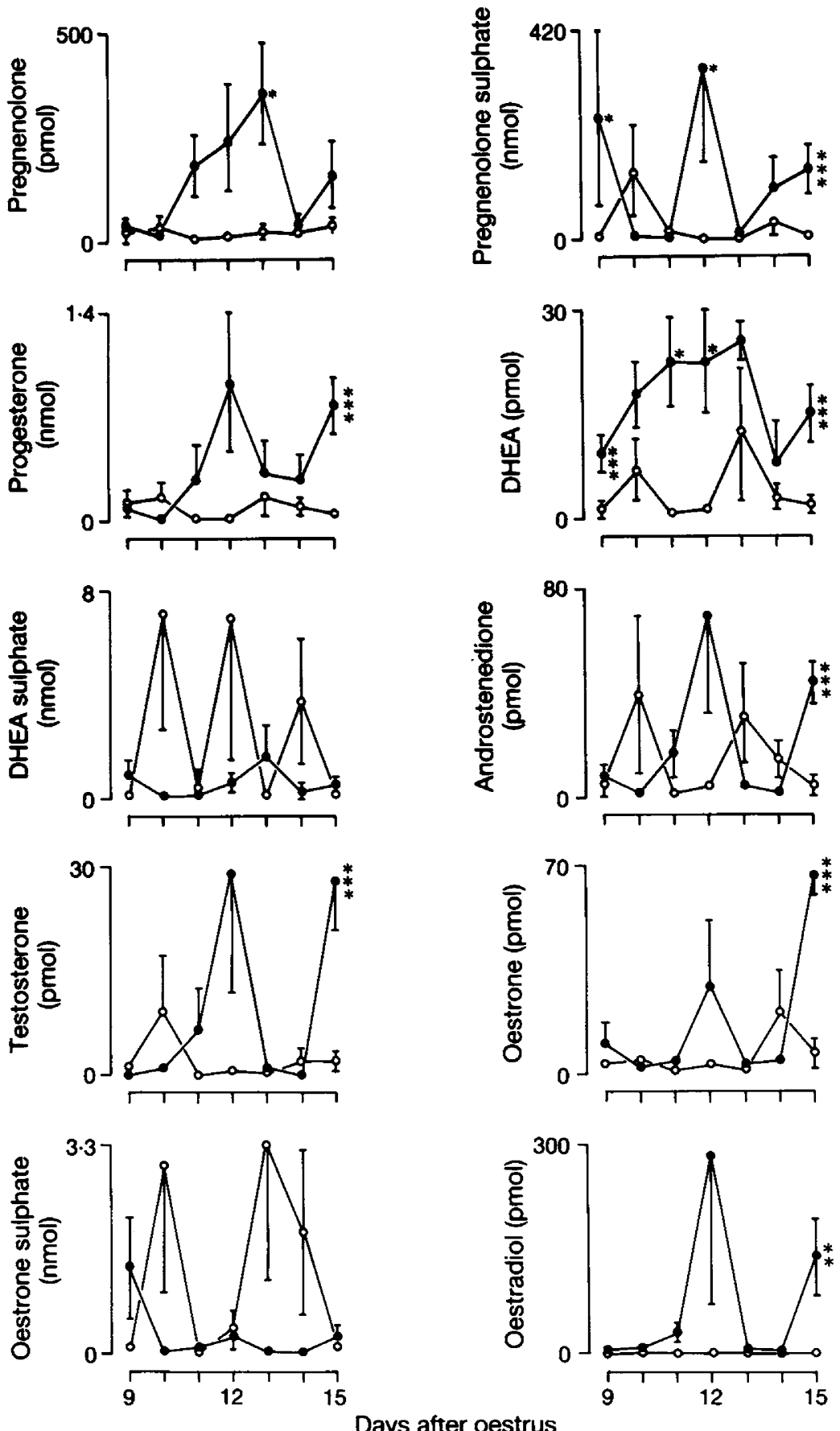

Days after oestrus

Text-fig. 1. Average ( \pm s.e.m.) total amounts of steroids in washings of single uterine horns of unmated $(O)$ and mated $(O)$ gilts on individual days between Days 9 and 15 after oestrus. For each day, non-pregnancy and pregnancy values were compared using a $t$ test: ${ }^{*} P<0.05$; ${ }^{* *} P<0.01 ;{ }^{* * *} P<0.001$. 
Table 2. Concentrations of steroids in free uterine fluid and in plasma of unmated and of mated gilts between Days 9 and 15 after oestrus

\begin{tabular}{|c|c|c|c|c|c|c|c|}
\hline \multirow{3}{*}{\multicolumn{2}{|c|}{ Steroid }} & \multicolumn{6}{|c|}{ Mean \pm s.e.m. steroid concentration (nM) } \\
\hline & & \multicolumn{3}{|c|}{ Unmated gilts } & \multicolumn{3}{|c|}{ Mated gilts } \\
\hline & & $\begin{array}{l}\text { Uterine fluid } \\
\quad(n=24)\end{array}$ & $\begin{array}{l}\text { Plasma } \\
(n=16)\end{array}$ & & $\begin{array}{l}\text { Uterine fluid } \\
\quad(n=20)\end{array}$ & $\begin{array}{l}\text { Plasma } \\
(n=16)\end{array}$ & \\
\hline $\mathrm{C}_{21}$ & $\begin{array}{l}\text { Pregnenolone } \\
\text { Pregnenolone sulphate } \\
\text { Progesterone }\end{array}$ & $\begin{array}{c}8 \cdot 04 \pm 1 \cdot 75 \\
1973 \pm 533 \\
14 \cdot 6 \pm 5 \cdot 8\end{array}$ & $\begin{array}{l}3 \cdot 36 \pm 0 \cdot 99 \\
37 \cdot 3 \pm 8 \cdot 4 \\
72 \cdot 7 \pm 12 \cdot 0\end{array}$ & $\begin{array}{l}* \\
* * * \\
* * *\end{array}$ & $\begin{array}{c}39 \cdot 37 \pm 13.39 \\
3812 \pm 1109 \\
17 \cdot 1 \pm 3 \cdot 9\end{array}$ & $\begin{array}{l}3.88 \pm 0.84 \\
25 \cdot 0 \pm 1 \cdot 9 \\
89 \cdot 2 \pm 6 \cdot 4\end{array}$ & $\begin{array}{l}* \\
* * \\
* * *\end{array}$ \\
\hline $\mathrm{C}_{19}$ & $\begin{array}{l}\text { DHEA } \\
\text { DHEA sulphate } \\
\text { Androstenedione } \\
\text { Testosterone }\end{array}$ & $\begin{array}{l}0 \cdot 24 \pm 0.06 \\
95 \cdot 2 \pm 26 \cdot 1 \\
1 \cdot 26 \pm 0.09 \\
0 \cdot 39 \pm 0 \cdot 12\end{array}$ & $\begin{array}{l}0.10 \pm 0.02 \\
0.61 \pm 0.10 \\
0.45 \pm 0.04 \\
0.85 \pm 0.18\end{array}$ & $\begin{array}{l}* \\
* * * \\
* * * \\
*\end{array}$ & $\begin{array}{c}10 \cdot 37 \pm 3 \cdot 24 \\
13 \cdot 3 \pm 3 \cdot 2 \\
2 \cdot 38 \pm 0 \cdot 40 \\
0 \cdot 76 \pm 0 \cdot 23\end{array}$ & $\begin{array}{l}0 \cdot 44 \pm 0 \cdot 10 \\
1 \cdot 34 \pm 0 \cdot 27 \\
1 \cdot 15 \pm 0 \cdot 14 \\
0 \cdot 80 \pm 0 \cdot 16\end{array}$ & $\begin{array}{l}* * \\
* * * \\
* *\end{array}$ \\
\hline$C_{18}$ & $\begin{array}{l}\text { Oestrone } \\
\text { Oestrone sulphate } \\
\text { Oestradiol }\end{array}$ & $\begin{array}{l}0.92 \pm 0.26 \\
47 \cdot 3 \pm 12 \cdot 1 \\
0 \cdot 26 \pm 0.12\end{array}$ & $\begin{array}{l}0.05 \pm 0.01 \\
0.32 \pm 0.04 \\
0.03 \pm 0.01\end{array}$ & $\stackrel{* *}{* * *}$ & $\begin{array}{l}3.07 \pm 0.73 \\
12.9 \pm 3.4 \\
4.31 \pm 1.03\end{array}$ & $\begin{array}{l}0 \cdot 10 \pm 0.05 \\
0 \cdot 68 \pm 0 \cdot 16 \\
0.03 \pm 0.01\end{array}$ & $\begin{array}{l}* * * \\
* * * \\
* * *\end{array}$ \\
\hline
\end{tabular}

Significantly different from value for free uterine fluid: ${ }^{*} P<0.05 ;{ }^{* *} P<0.01 ;{ }^{* * *} P<0.001$ (Student's $t$ test).

Table 3. Analysis of differences between pregnant and non-pregnant gilts in respect to concentrations of steroids in free uterine fluid and in plasma

\begin{tabular}{|c|c|c|c|c|c|}
\hline & \multirow{2}{*}{ Steroid } & \multicolumn{2}{|c|}{$\begin{array}{l}\text { Significance of difference } \\
\text { between concentrations of } \\
\text { pregnant and non-pregnant } \\
\text { gilts }\end{array}$} & \multicolumn{2}{|c|}{ Pregnant/non-pregnant ratio } \\
\hline & & Uterine fluid & Plasma & Uterine fluid & Plasma \\
\hline $\mathrm{C}_{2 \mathrm{t}}$ & $\begin{array}{l}\text { Pregnenolone } \\
\text { Pregnenolone sulphate } \\
\text { Progesterone }\end{array}$ & $\begin{array}{l}* \\
\text { NS } \\
\text { NS }\end{array}$ & $\begin{array}{r}\text { NS } \\
* \\
\text { NS }\end{array}$ & $\begin{array}{l}4.90 \\
1.93 \\
1 \cdot 17\end{array}$ & $\begin{array}{l}1 \cdot 15 \\
0.67 \\
1.23\end{array}$ \\
\hline$C_{19}$ & $\begin{array}{l}\text { DHEA } \\
\text { DHEA sulphate } \\
\text { Androstenedione } \\
\text { Testosterone }\end{array}$ & $\begin{array}{c}* * \\
* * \\
* * \\
\text { NS }\end{array}$ & $\begin{array}{l}* * \\
* * \\
* * * \\
\text { NS }\end{array}$ & $\begin{array}{c}43 \cdot 2 \\
0.14 \\
1.89 \\
1.95\end{array}$ & $\begin{array}{l}4 \cdot 40 \\
2 \cdot 20 \\
2 \cdot 56 \\
0 \cdot 94\end{array}$ \\
\hline $\mathrm{C}_{18}$ & $\begin{array}{l}\text { Oestrone } \\
\text { Oestrone sulphate } \\
\text { Oestradiol }\end{array}$ & $\begin{array}{r}* * \\
* \\
* * *\end{array}$ & $\begin{array}{l}\text { NS } \\
* \\
\text { NS }\end{array}$ & $\begin{array}{c}3.34 \\
0.27 \\
16 \cdot 6\end{array}$ & $\begin{array}{l}2 \cdot 00 \\
2 \cdot 13 \\
1 \cdot 00\end{array}$ \\
\hline
\end{tabular}

NS, not significant; ${ }^{*} P<0.05 ;{ }^{* *} P<0.01 ;{ }^{* * *} P<0.001$ (Student's $t$ test).

Between Days 9 and 15 after oestrus, average levels of DHEA, DHEA sulphate, androstenedione and oestrone sulphate in plasma of pregnant gilts exceeded non-pregnant concentrations while pregnenolone sulphate levels were diminished $(P<0.05$; Tables $2 \& 3)$. Daily plasma steroid levels between Days 9 and 15 after oestrus/coitus are summarized in Text-fig. 3 .

Linear regressions between steroid properties of uterine fluids and plasma, numbers of CL, days after oestrus and days post coitum, were not statistically significant $(P>0.05)$. 

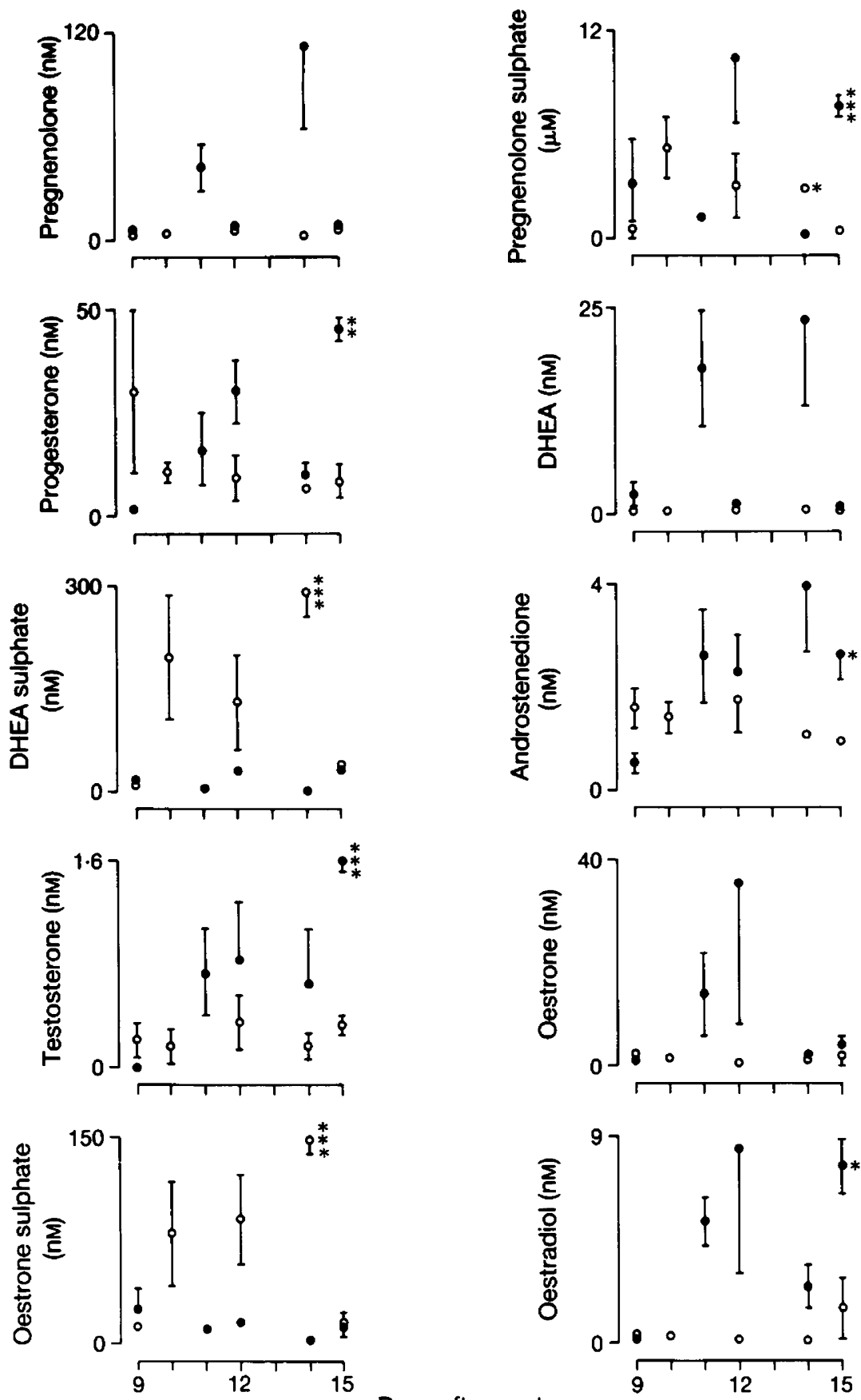

Days after oestrus

Text-fig. 2. Average ( \pm s.e.m.) concentrations of steroids in free uterine fluid recovered from single uterine horns of unmated $(O)$ and mated $(O)$ gilts on individual days between Days 9 and 15 after oestrus. The data represent only those uterine horns from which free fluid could be recovered (non-pregnant, $n=24$; pregnant, $n=20$ ). For each day, non-pregnancy and pregnancy values were compared using a $t$ test: ${ }^{*} P<0.05 ;{ }^{* *} P<0.01 ;{ }^{* *} P<0.001$. 

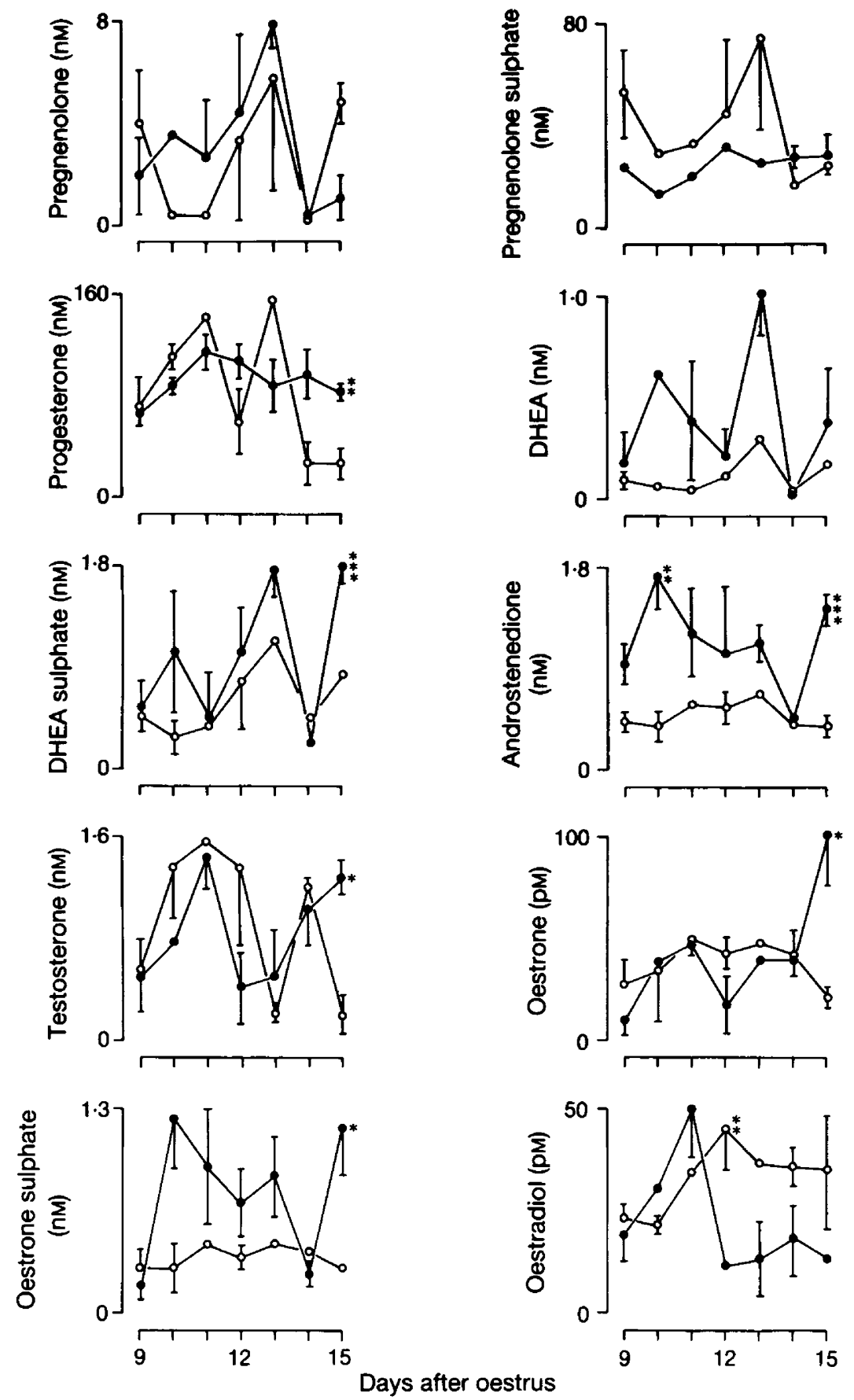

Text-fig. 3. Average ( \pm s.e.m.) concentrations of steroids in plasma of unmated $(O)$ and mated (๑) gilts on individual days between Days 9 and 15 after oestrus. For each day, non-pregnancy and pregnancy values were compared using a $t$ test: ${ }^{*} P<0.05 ;{ }^{* *} P<0.01$; ${ }^{* * *} P<0.001$. 


\section{Discussion}

Significant amounts of steroid hormones were present in uterine washings recovered from unmated sows between Days 9 and 15 after oestrus (Table 1), with evidence for a marked (50- to 150-fold) concentration of the sulphoconjugates of pregnenolone, DHEA and oestrone in free uterine fluid compared with plasma levels (Table 2). Further accumulation of pregnenolone, progesterone, DHEA, testosterone, oestrone and oestradiol occurred in uterine fluid during pregnancy $(P<0.05$; Table 1; Text-fig. 1).

The higher levels of oestrone and oestradiol in uterine fluids of gilts between Days 9 and 15 of pregnancy (Table 1; Text-fig. 1) are consistent with oestrogen synthesis by dispersed pig blastocyst tissues (Heap et al., 1981) and the results concur with those of Ford, Christenson \& Ford (1982) in respect to the predominance of oestradiol in uterine fluid (Tables $1 \& 2$ ) and their evidence for concentration of oestradiol in uterine venous plasma. Levels of oestrone and oestradiol in the washings of gravid uteri increased after about Day 11 of pregnancy, and were significantly higher $(P<0.05)$ than non-pregnancy values by Day 15 after oestrus (Text-fig. 1). This result is in accord with previous reports that oestrogen synthesis by pig blastocyst tissues in vivo is initiated between Days 10 and 12 of gestation (Heap, Perry, Gadsby \& Burton, 1975).

Oestrone sulphate levels in uterine fluid were similar for pregnant and non-pregnant animals (Table 1). However, concentrations of oestrone sulphate in plasma were elevated in pregnancy $(P<0.05$; Table 2; see Text-fig. 3), this being consistent with oestrone secretion by blastocyst tissues as proposed by Heap et al. (1981), its accumulation in histotroph $(P<0.001$; Table 2; Text-fig. 1), sulphation in uterine or other maternal tissues (Pack \& Brooks, 1974; Pack, Brooks, Dukelow \& Brooks, 1979; Meyers et al., 1983), and release to the maternal circulation as the sulphoconjugate.

The preferred precursor and pathway for oestrogen synthesis by pig conceptuses have not previously been identified. However, since ovarian progesterone is not an obligatory precursor, Flint et al. (1979) and Heap et al. (1981) have proposed that oestrogens are synthesized by the blastocyst from adrenal progesterone or pregnenolone, or from cholesterol or acetate. The immediate oestrogen precursor measured in the present study, androstenedione, was concentrated in uterine fluid relative to plasma in pregnant and in non-pregnant gilts $(P<0.01$; Table 2$)$, although mechanisms inducing the pregnancy-associated increases in concentration of this steroid in plasma and in uterine fluid $(P<0.001$ and $P<0.01$ respectively; Tables $2 \& 3$; see Text-figs $2 \&$ 3 ) remain to be determined. Furthermore, the accumulation and concentration of androgens in uterine fluid between Days 9 and 15 of pregnancy (Tables $1,2 \& 3$; Text-figs $1 \& 2$ ) provide a potentially important source of oestrogen precursor, but whether these events reflect changes in enzyme activity in maternal or embryonic tissues remains unresolved. Besides being potential oestrogen precursors, androstenedione and testosterone may be important in their own right, as both are potent protein anabolic agents which may play a role in the exponential increase in protein content of pig embryos between Days 9 and 15 after coitus (Anderson, 1978; Wright et al., 1983).

Pig blastocyst tissues show arylsulphatase activity (Flint et al., 1979) and are able to synthesize oestrogen from pregnenolone and DHEA in vitro (Heap et al., 1981). The steroịd sulphoconjugates are also, therefore, potential precursors for blastocyst steroidogenesis and, with the high concentration of pregnenolone sulphate $(3.81 \mu \mathrm{M})$ and of DHEA sulphate $(13.3 \mathrm{nM})$ in free uterine fluid of pregnant gilts (Table 2), oestrogen synthesis from these sources must be considered.

The accumulation and concentration of the sulphoconjugates of pregnenolone and of DHEA in uterine fluid of unmated animals $(P<0.001$; Tables $1 \& 2)$ indicates a concentrating mechanism for sulphoconjugates which is specific to maternal tissues. Further accumulation of pregnenolone sulphate in uterine fluid during pregnancy (Table 1; Text-fig. 1) could then be attributable to induction of further sulphotransferase activity during early pregnancy (Dwyer \& Robertson, 1980) by progestagens or other pregnancy-associated hormones, as previously demonstrated in cultured human endometrium (Clarke, Adams \& Wren, 1982). As average pregnenolone sulphate 
concentrations were lower in plasma of pregnant compared with non-pregnant sows between Days 9 and 15 after oestrus $(P<0 \cdot 05$, Table 3 ), while pregnenolone concentrations were similar (Table 3 ), we propose that pregnenolone sulphate in uterine fluid derives from the pool of pregnenolone sulphate in maternal plasma, rather than from the plasma pregnenolone pool. Furthermore, as there is no evidence to suggest that steroid production rates of pregnant and non-pregnant gilts differ between Days 9 and 12 after oestrus, the plasma pregnenolone sulphate values shown in Textfig. 3 indicate that the rate of clearance of this steroid sulphate from maternal plasma is higher in pregnant animals before Day 12 after oestrus. Precise mechanisms of transfer of steroids and/or steroid conjugates across the pig endometrium have not yet been elucidated.

Our own in-vitro studies have identified sulphokinase activity in intact pig blastocysts, and have shown that pregnenolone sulphate can be metabolized to pregnenolone and to progesterone by blastocysts cultured between Days 3 and 8 after fertilization (B. A. Stone \& R. F. Seamark, unpublished data). If pregnenolone sulphate concentrated in uterine luminal fluids is metabolized to progesterone by pig blastocysts in vivo, this progesterone may be concentrated within the blastocoele cavity (Heap et al., 1981) and at the trophectoderm boundary layer where it can then provide immune cytoprotection for the embryo (Siiteri et al., 1977) or, if released, stimulate secretory activity by the endometrium (Knight et al., 1973; Schlosnagle et al., 1974; Roberts, Bazer, Baldwin \& Pollard, 1976; Adams et al., 1981; Fazleabas et al., 1982). Higher levels of progesterone in fluids recovered from pregnant tracts in the present study $(P<0.05$; Table 1$)$ are consistent with progesterone synthesis and secretion by preimplantation pig blastocysts, although concentrations of progesterone in uterine fluid and in plasma of pregnant and of non-pregnant gilts were similar between Days 9 and 15 after oestrus $(P>0.05$; Table 3$)$. Uterine metabolism of progesterone released by blastocysts is thus indicated, with no direct contribution by conceptus tissue to the maternal progesterone pool (see Robertson \& King, 1974). Similarly, large quantities of progesterone which are synthesized by placental tissues of pigs later in gestation appear to be metabolized locally, and do not increase systemic progesterone levels (Kukoly, Knight \& Notter, 1984).

Higher levels of progesterone in plasma of pregnant gilts at Day 15 after oestrus $(P<0.05$; Text-fig. 3) are consistent with luteotrophic effects of oestrogens (Gardner, First \& Casida, 1963; Bazer \& Thatcher, 1977; Frank, Bazer, Thatcher \& Wilcox, 1978; Ford \& Magness, 1980) which are secreted into the uterine lumen of pregnant sows at this time (Text-fig. 1).

On the basis of our results, we suggest that the high levels of the sulphoconjugates of pregnenolone and of DHEA in uterine fluid of the early pregnant pig serve as an important precursor pool for steroid synthesis by preimplantation pig embryos in vivo.

We thank Mr P. A. Heap and staff of the Northfield Pig Research Unit, South Australian Department of Agriculture, for their care of the experimental animals. Sylvia Deam provided technical support. This study was funded by the Australian Pig Industry Research Committee.

\section{References}

Adams, K.L., Bazer, F.W. \& Roberts, R.M. (1981) Progesterone-induced secretion of a retinol-binding protein in the pig uterus. J. Reprod. Fert. 62, 39-47.

Aitken, R.J. (1979) Uterine proteins. In Oxford Reviews of Reproductive Biology, Vol. 1, pp. 351-382. Ed. C. A. Finn. Oxford Science Publications, Oxford.

Anderson, L.L. (1978) Growth, protein content and distribution of early pig embryos. Anat. Rec. 190, 143-154.

Basha, S.M.M., Bazer, F.W. \& Roberts, R.M. (1979) The secretion of a uterine specific, purple phosphatase by cultured explants of porcine endometrium; dependency upon the state of pregnancy of the donor animal. Biol. Reprod. 20, $431-441$.

Basha, S.M.M., Bazer, F.W. \& Roberts, R.M. (1980) Effect of the conceptus on quantitative and qualitative aspects of uterine secretion in pigs. $J$. Reprod. Fert. 60, 41-48.

Bazer, F.W. (1975) Uterine protein secretions: relationship to development of the conceptus. J. Anim. Sci. 41, 1376-1382.

Bazer, F.W. \& Thatcher, W.W. (1977) Theory of 
maternal recognition of pregnancy in swine based on oestrogen controlled endocrine versus exocrine secretion of prostaglandin $F_{2 \alpha}$ by the uterine endometrium. Prostaglandins 14, 397-401.

Borland, R.M., Erickson, G.F. \& Ducibella, T. (1977) Accumulation of steroids in rabbit preimplantation blastocysts. J. Reprod. Fert. 49, 219-224.

Bruning, P.F., Jonker, K.M. \& Boerema-Baan, A.W. (1981) Adsorption of steroid hormones by plastic tubing. J. Steroid Biochem. 14, 553-555.

Clarke, C.L., Adams, J.B. \& Wren, B.G. (1982) Induction of oestrogen sulphotransferase in the human endometrium by progesterone in organ culture. $J$. clin. Endocr. Metab. 55, 70-75.

Clarke, G.M. (1969) Statistics and Experimental Design, pp. 55-57. Edward Arnold, London.

Dwyer, R.J. \& Rohertson, H.A. (1980) Oestrogen sulphotransferase activities in the endometrium of the sow and ewe during pregnancy. J. Reprod. Fert. 60, 187-191.

Fazleabas, A.T., Bazer, F.W. \& Roberts, R.M. (1982) Purification and properties of a progesteroneinduced plasmin trypsin inhibitor from uterine secretions of pigs and its immunocyto-chemical localization in the pregnant uterus. J. biol. Chem. 257, 6886-6897.

Flint, A.P.F., Burton, R.D., Gadsby, J.E., Saunders, P.T.K. \& Heap, R.B. (1979) Blastocyst oestrogen synthesis and the maternal recognition of pregnancy. In Maternal Recognition of Pregnancy (Ciba Fdn Symp. N.S. 64), pp. 209-228. Ed. J. Whelan. Excerpta Medica, Amsterdam.

Ford, S.P. \& Magness, R.R. (1980) Effect of intra-uterine infusions of estradiol-17 beta on luteal function in nonpregnant sows. J. Anim. Sci. 51 (Suppl. 1), 279, Abstr.

Ford, S.P., Christenson, R.K. \& Ford, J.J. (1982) Uterine blood flow and uterine arterial, venous and luminal concentrations of oestrogens on Days 11,13 and 15 after oestrus in pregnant and non-pregnant sows. $J$. Reprod. Fert. 64, 185-190.

Frank, M., Bazer, F.W., Thatcher, W.W. \& Wilcox, C.J. (1978) A study of prostaglandin F2- $\alpha$ as the luteolysin in swine. IV. An explanation for the luteotrophic effect of oestradiol. Prostaglandins 15, $151-160$.

Gadsby, J.E. \& Heap, R.B. (1978) Steroid hormones and their synthesis in the early embryo. In Novel Aspects of Reproductive Physiology, pp. 263-283. Eds C. H. Spilman \& J. W. Wilks. SP Medical and Scientific Books, New York.

Gardner, M.L., First, N.L. \& Casida, L.E. (1963) Effect of exogenous estrogens on corpus luteum maintenance in gilts. J. Anim. Sci. 22, 132-134.

Geisert, R.D., Thatcher, W.W., Roberts, R.M. \& Bazer, F.W. (1982a) Establishment of pregnancy in the pig. III. Endometrial secretory response to estradiol valerate administered on day 11 of the estrous cycle. Biol. Reprod. 27, 957-965.

Geisert, R.D., Renegar, R.H., Thatcher, W.W., Roberts, R.M. \& Bazer, F.W. (1982b) Establishment of pregnancy in the pig. I. Interrelationships between preimplantation development of the pig blastocyst and uterine endometrial secretions. Biol. Reprod. 27, 925-939.
Heap, R.B., Perry, J.S., Gadsby, J.E. \& Burton, R.D. (1975) Endocrine activities of the blastocyst and early embryonic tissue in the pig. Biochem. Soc. Trans. 3, $1183-1188$.

Heap, R.B., Flint, A.P.F., Gadsby, J.E. \& Rice, C. (1979) Hormones, the early embryo and the uterine environment. J. Reprod. Fert. 55, 267-275.

Heap, R.B., Flint, A.P.F., Hartmann, P.E., Gadsby, J.E., Staples, L.D., Ackland, N. \& Hamon, M. (1981) Oestrogen production in early pregnancy. J. Endocr. 89, $77 P$-94P.

Henricks, D.M., Guthrie, H.D. \& Handlin, D.L. (1972) Plasma estrogen, progesterone and luteinizing hormone levels during the estrous cycle in pigs. Biol. Reprod. 6, 210-218.

Knight, J.W., Bazer, F.W. \& Wallace, H.D. (1973) Hormonal regulation of porcine uterine secretions. $J$. Anim. Sci. 36, 546-553.

Kukoly, C.A., Knight, J.W. \& Notter, D.R. (1984) Porcine placental steroidogenesis throughout gestation. J. Anim. Sci. 59, 370, Abstr.

Li, J.C.R. (1969) Siatistical Inference, pp. 279-348. Edwards Brothers, Ann Arbor.

Meyers, S.A., Lozon, M.M., Corombos, J.D., Saunders, D.E., Hunter, K., Christenson, C. \& Brooks, S.C. (1983) Induction of porcine uterine estrogen sulfotransferase activity by progesterone. Biol. Reprod. 28, $1119-1128$.

Murray, F.A., Bazer, F.W., Wallace, H.D. \& Warnick, A.C. (1972) Quantitative and qualitative variations in the secretion of protein by the porcine uterus during the estrous cycle. Biol. Reprod. 7, 314-320.

Pack, B.A. \& Brooks, S.C. (1974) Cyclic activity of estrogen sulfotransferase in the gilt uterus. Endocrinology 95, 1680-1690.

Pack, B.A., Brooks, C.L., Dukelow, W.R. \& Brooks, S.C. (1979) The metabolism and nuclear migration of estrogen in porcine uterus throughout the implantation process. Biol. Reprod. 20, 545-551.

Perry, J.S. (1981) The mammalian fetal membranes. $J$. Reprod. Fert. 62, 321-335.

Roberts, R.M., Bazer, F.W., Baldwin, N. \& Pollard, W.E. (1976) Progesterone induction of lysozyme and peptidase activities in the porcine uterus. Archs. Biochem. Biophys. 177, 499 507.

Robertson, H.A. \& King, G.J. (1974) Plasma concentrations of progesterone, oestrone, oestradiol-17 $\beta$ and of oestrone sulphate in the pig at implantation, during pregnancy and at parturition. J. Reprod. Fert. 40, 133-141.

Schlosnagle, D.C., Bazer, F.W., Tsibris, J.C.M. \& Roberts, R.M. (1974) An iron-containing phosphatase induced by progesterone in the uterine fluid of pigs. J. biol. Chem. 249, 7574-7579.

Scofield, A.M., Clegg, F.G. \& Lamming, G.E. (1974) Embryonic mortality and uterine infection in the pig. J. Reprod. Fert. 36, 353-361.

Seamark, R.F. \& Lutwak-Mann, C. (1972) Progestins in rabbit blastocysts. J. Reprod. Fert. 29, 147-148.

Siiteri, P.K., Febres, F., Clemens, L.E., Chang, R.J., Gondos, B. \& Stites, D. (1977) Progesterone and maintenance of pregnancy: is progesterone Nature's immunosuppressant? Ann. N.Y. Acad. Sci. 286, 384-397.

Stone, B.A., Whyte, P.B.D., Pointon, A.M., Quinn, P. \& 
Heap, P.A. (1984) Transfer of pig embryos collected from a sow slaughtered at an abattoir. Aust. vet. $J$. 61, 30-31.

Wright, R.W., Jr, Grammer, J., Bondioli, K., Kuzan, F. \& Menino, A., Jr (1983) Protein content and volume of early porcine blastocysts. Anim. Reprod. Sci. 5, 207-212.

Zavy, M.T., Bazer, F.W., Thatcher, W.W. \& Wilcox,
C.J. (1980) A study of prostaglandin $F_{2 \alpha}$ as the luteolysin in swine. V. Comparison of prostaglandin $F$, progestins, estrone and estradiol in uterine flushings from pregnant and non-pregnant gilts. Prostaglandins 20, 837-851.

Received 25 January 1985 